\title{
DEVELOPMENT OF GIS DATABASE AND FACILITY MANAGEMENT SYSTEM: ASSET AND SPACE IN UKM
}

\author{
Mohd Aizat Saiful Bahri ${ }^{1}$, Khairul Nizam Abdul Maulud ${ }^{2}$, Muhammad Amartur Rahman ${ }^{1}$, Aslinda Oon Binti Ridzuan Oon ${ }^{5}$, Adi \\ Irfan Che Ani ${ }^{3}$ Che Hafify Che Hashim ${ }^{1}$, Hairi Karim ${ }^{6}$ Muhammad Syahidi Hasbullah ${ }^{1}$ Mohd Za' Im Aziz ${ }^{4}$ \\ ${ }^{1}$ Prasarana- UKM, Universiti Kebangsaan Malaysia, Bangi - \{maizat; amarturr $\} @$ ukm.edu.my \\ ${ }^{2}$ Earth Observation Centre, Universiti Kebangsaan Malaysia. - knam@ukm.edu.my \\ ${ }^{3}$ Pusat Citra UKM, Universiti Kebangsaan Malaysia, Bangi \\ ${ }^{4}$ Khazanah-UKM, Universiti Kebangsaan Malaysia, Bangi \\ ${ }^{5}$ Information Technology Centre, Universiti Kebangsaan Malaysia, Bangi \\ ${ }^{6}$ 3D GIS Research Lab, Faculty of Build Environment and Survey, Universiti Teknologi Malaysia, \\ 81310, Johor Bahru, Johor, Malaysia. wmhairigis@gmail.com
}

KEY WORDS: Geodatabase, facility management system, GIS for asset and space, geo-space university management.

\begin{abstract}
:
Facility Management (FM) has becoming a crucial aspect in providing better service to the client/tenant or public as well as to minimize the maintenance cost. Group of buildings bounded by a defined boundary/spatial space such as a college, university, city or even a country have to manage their assets and space systematically with maximum potential/usage and minimum maintenance cost. Incorporating GIS plays innovative and effective role in asset and space FM especially. There are a lot of research and suggestions for it, but implementation is still average and quite new in Malaysia. University Kebangsaan Malaysia (UKM Bangi) has taken initiative to perform such idea with a full scale implementation. Currently, UKM utilizes GIS in nine modules, where one of the main module called SEPADU , an internal use module system for asset and space information system. This paper describes the implementation of integrated GIS solution in information system. Spatial data acquisition, database development and system for FM will be discussed in this paper.
\end{abstract}

\section{INTRODUCTION}

\subsection{Background Study}

Asset and space are one of the important sections in facility management of any organization. Space management is a process of determining space requirements, identifying deficiencies, and allocating available space to user in an equitable way, monitoring use, assisting users with space usage, problems, and resolving space problems (Marion W. Mwaniki, Patroba A. Odera, 2012). Managing facilities such as space require a consistence commitment for storing, querying, and updating spatial and information database. Efficient space management will maximize the potential of the space in term of function, quality and efficiency within organization control boundary. Space can be utilized in full capacity if the management know the condition of the space before using it.

Assets in space also required through organization management since it involves a lot of cost especially for maintenance, upgrade or disposed upon expired/damaged. Assets within the space (assets in a building/room) are much more difficult to monitor because of lack proper recording system. Top management in organizations does not only want to know the value of the asset but also the existence of the asset in term of location and it'condition. Conventional method of asset management system comprises two main components: a relational database containing the asset data and a set of add-on analysis for decision-support modules. The retrieval is basically stored in relational information database (IT) that can be analysed and automated report can be generated (Mahmoud M.R Halfawy, et al., 2006).
Nowadays with the advancement of technology, relationship between asset and space can be achieved with an assistant of Geographical Information System (GIS). GIS is a term refers to a digital system designed to capture, store, manipulate, analyse, manage, present and disseminate spatial or geographic data (Cantwell and Milem, 2010; Hairi et al, 2019) for public or decision makers. The system utilises spatial data and attributes (related tabular information/characteristic of its spatial data) for decision making process of a particular area such as for development, environment protection, security, businesses development, taxation, asset management and other inventory tasks.

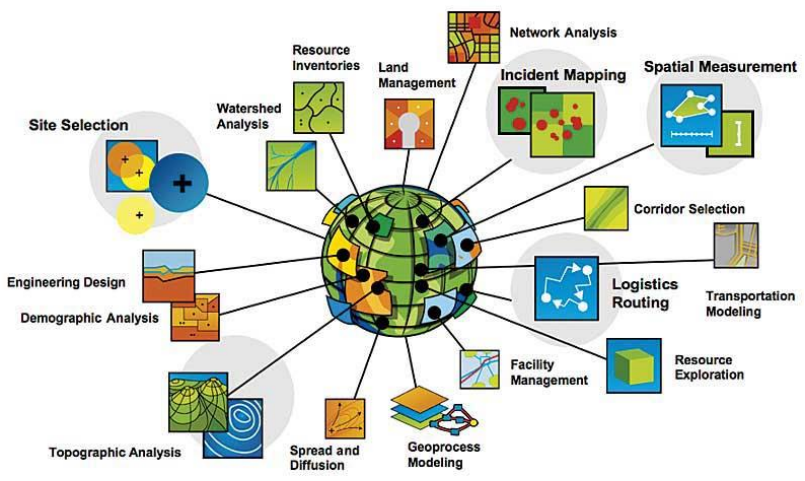

Figure 1: Applied GIS around the world across disciplines, professions and organizations (ESRI, 2007).

Longley, et al., (2001) mentioned that GIS is taking part in handling location element for any feature or space; spatial analysis non-spatial statistics (Bahri S. et al., 2014). GIS interface allow the interaction between asset inventory database and space to graphically represent in spatial context. 
Integration between space management system and asset management system using GIS is now available through many developments of GIS software such as ArcGIS from ESRI and any open sources software such as QGIS platform.

Many examples on establishing the system can be retrieved from ESRI product by referring to the published book GIS Best Practice: Facilities Management (2010). Establish system such as San Diego Port Authority using integration of GIS and Information Technology System (IT) and document system help to smooth out the operation of the port that generated revenue of $\$ 133.7$ million in 2007 (Esri, 2010). This show how much GIS helps improving assets and space management.

However, GIS data for Universiti Kebangsaan Malaysia (UKM) originally is not in digital forms. Most of them are still in old hardcopy drawings, some in AutoCAD format without any coordinate system. Most of the required data are not available and need to be collected at sites such as underground utility maps, trees (landscape) and others.

\subsection{Project Aim and Objectives}

\subsubsection{Aim}

To establish a GIS-based platform system which integrate all spatial datasets of buildings and assets as maintenance information platform at all level of users.

\subsubsection{Objectives}

- To produce a spatial database of as-built drawing building floors for each building in UKM.

- To establish a relationship and topology of non-spatial data (e.g. Ufast, a treasuring system in UKM) and spatial database.

- To design and develop an internal GIS-Facility Management System which UKM authorized management team shall have related space and asset information.

This paper basically been divided into five major sections; introduction, literature (facility management, GIS data and system), current online mapping system, the developed facility management database for assets and spaces, and lastly brief conclusion.

\section{THE LITERATURE}

This section is divided into two sub-sections; facility management, GIS dataset and facility management based on GIS application sections.

\subsection{Facilities Management}

Most of the government or organization realize that providing good quality environment lead to good performance and help in sustaining operation for longer period. In order to provide good environment to the people especially students, the quality of education facilities and assets need to be monitored and kept in top condition; especially within university campus. This required a good and well practice facilities management. According to FMA (2012), facilities management (FM) can be define as process of guiding and managing the operations and maintenance of buildings, precincts and community infrastructure on behalf of property owner. FM has been practicing for decades since it was formally acknowledged in the United State and Canada in 1975 (Che Mohd Nasir, Siti Nuratirah, 2018).

In Malaysia, definition of asset and facilities management can be befined from Manual on Asset and Facilities Management, CIDB 2010: "A Strategic Management towards preservation of asset and facilities value throughout its life cycle.". From the manual, the term of asset and facilities means built environment asset and facilities that are man-made asset and facilities that are physical in nature - not financial asset and facilities such as unit trusts introduced by the government several years back. The definition that has gained the most preference by the industry players to define facilities management in Malaysia is the management of multidisciplinary activities to ensure continuous functionality of the built environment by linking and integrating people, place, processes and technology. (Abdul Hakim bin Mohammed, 2006)

The scope of FM discipline covers all aspects of property, space environment control, health and safety and support services. (Mohd Nazali Mohd and Micheal Pitt, 2008). In Malaysia, property assets in the form of building and infrastructure always been manage by an in-house, outsources service team or combination of both of it. Stakeholders of the properties commonly take the cost of maintenance as the main factor into consideration in order to choose which option is better. The most efficient option must be chosen without compromise the quality of the maintenance service so that the quality of the asset can be keep at its highest.

FM in this paper/section only covers on the assets and space management at UKM Bangi. As for the project development progress, we intended to manage UKM space and assets (buildings, man-made structure and others) for a better management with the long term goal as to minimize the cost for maintenance and better management in the future.

\subsection{GIS Dataset}

A geographic information system (GIS) is a set of technology procedure designed to capture, store, manipulate, analyse, manage, present (Cantwell and Milem, 2010) and disseminate spatial or geographic data for public or decision makers. There are two primary features of GIS data; locational data specify the spatial position of entities and while attribute describing their characteristics (Manson et al., 2015). GIS system utilises spatial data and attributes (related tabular information/characteristic of its spatial data) for decision making process of a particular area (e.g. UKM for spatial inventory).

GIS database or geospatial database contain information that display geographical surface that support aspect of space and offer spatial data types in its data model and query language (Grace L. Samson, et al., 2017). GIS database generally possess two elements that are spatial data and non-spatial data. Spatial data is the data that display geographical information regarding physical and space while non-spatial data is the data that show either qualitative or quantitative value. Spatial data modelling is one of the crucial elements in GIS database and it is divided into two categories that are vector data model and raster data model as illustrated in Figure 2, while Figure 3 shows the comparison nature for both categories in modelling and managing the world in digital computer system. 


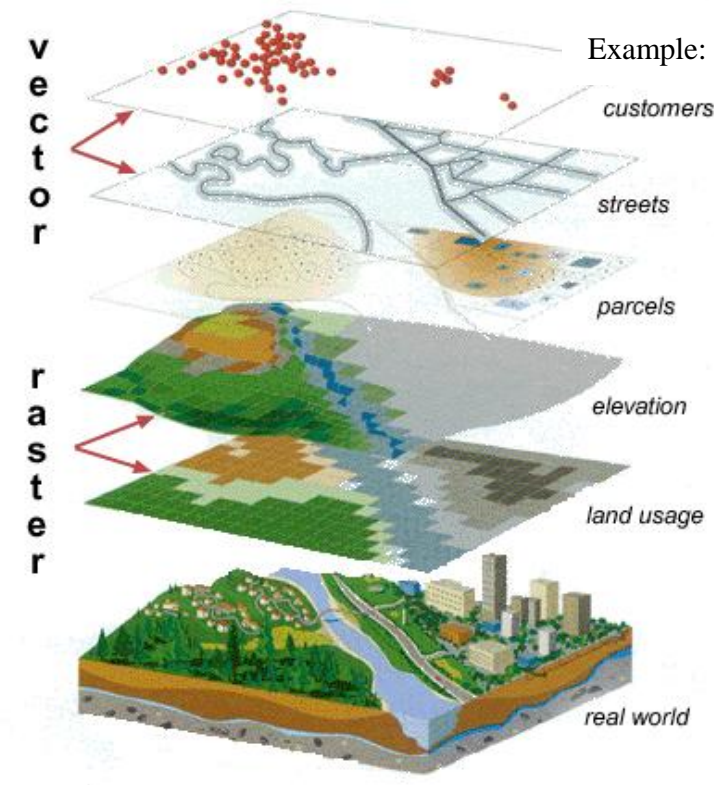

Figure 2. Illustration of vector and raster data model in GIS.

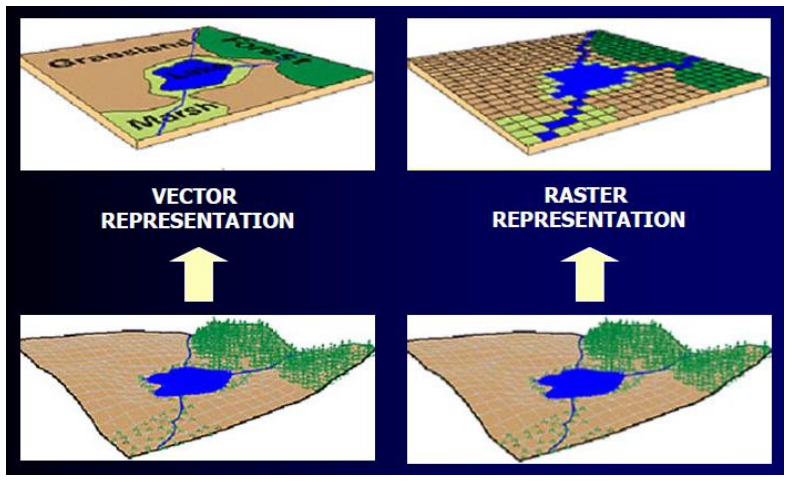

Figure 3: Comparison nature and presentation of vector and raster spatial model.

\subsubsection{Vector Data Model}

Vector data model is represented in three (3) types; point that have coordinate value, line shows distance, and polygon that represent a boundary of empty space. (Sabi'u, N., et al., 2015). Vector data can be obtained from different methods such as by using raster analog scanning and then digitizing into vectors forms (Grimshaw, 1994), on site data collection, digitizing from images and so on.

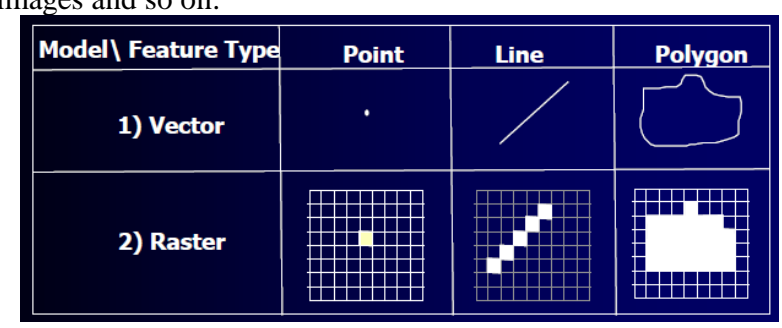

Figure 4: Comparison nature of vector and raster in point line and polygon shape/components.
The term raster implies for regular spaced grid - consists of rows and column of pixels. Raster uses a single value to represent a multiplicity of parameters e.g. elevation and others. The second types of raster category are digital images which support combination of three or more values such as $\mathrm{RGB} /$ multiple bands (Figure 5).

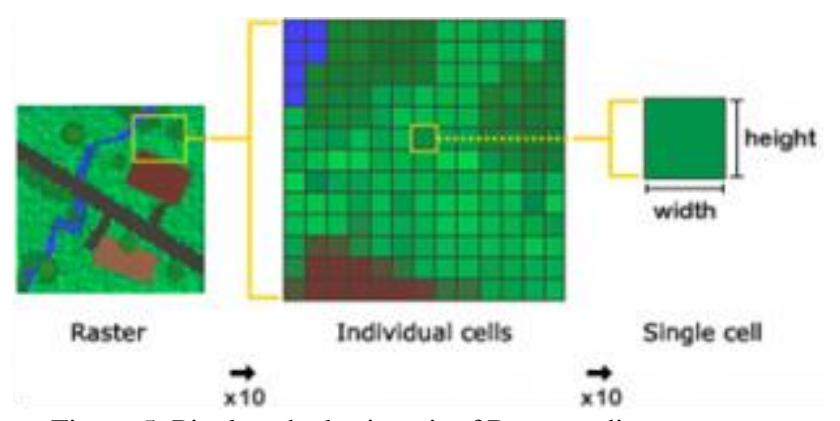

Figure 5. Pixel as the basic unit of Raster - discrete type (GICHD, 2016)

Raster can be categorised into two main groups; discrete and continue. An example of discrete is a grid represents of land cover class/soil type (unconnected/non-relational neighbouring objects) while Digital Elevation/Terrain Model (DEM/DTM) is an example of continues raster (seamless). Later, raster could be sub-divided into several groups include but not limited to; DEM, satellite imageries, orthophotos, binary scanned files, graphics files, chloropleth scanned maps, attribute based raster (e.g. land use, land covers) non-spatial dimension parameters (e.g. temperature, time stamp/video recording etc) and others.

\subsubsection{Data Collection Method}

There are various methods used to collect GIS data in this project such as from survey data (topography and underground utility detection), remote sensing, orthophoto image and DTM (using UAV drone) and secondary data (scanned map, drawing etc).

\section{a. Survey Data}

The in situ data where researchers went to the site to collect ground measurement consisting information of location coordinate and attribute of a feature layer. They used surveying instruments such as total stations, Real Time Kinematik (RTK) GNSS receiver to collect the data on ground data such as spot height and building footprint. The technique are based on transferring XYZ of a known point to the measured features or using Global Navigation Satellite System (GNSS) such as Global Position System (GPS). GNSS provides simple solution to "ground truthing GIS" with close to $1 \mathrm{~cm}$ accuracy level with costtime effective, easy to use, globally available (day and night), accurate and provide 3-dimensional data (Ewan Masters, et al., 1994).

\section{b. Remote Sensing}

Remote sensing is the process of capturing data of object or phenomenon without be in contact with it. Data derive from remote sensing is very useful for GIS because remote sensing data basically in raster format, the data can be cost effective for subsequent analysis or modelling application (Ross S. Lunetta, et al., 1991). Remote sensing data can be 
in many forms, commonly use are satellite image data and Unmanned Aerial Vehicle (UAV) data.

In this project, UKM has acquired Orthophoto imagery and Digital Terrain Model (DTM) from UAV data collection. These data are very useful as a basemap or reference for other dataset such as surveyed data and secondary data. Orthophoto provides a very sharp and accurate image references (from the top) for UKM while DTM provide submeter height accuracy of the terrain elevation for the whole UKM boundary (with sub-meter accuracy of ZY 1m resolution).

\section{c. Secondary Data}

Secondary data is an indirect method used to utilize the existing available data either in digital data or hard copy data (old map/as-built drawing). Digital data could be found in various existing format such as CAD, .*.tab (Mapinfo), *.shp (shapefile), *.tiff (scanned drawing map), tabular and other supported formats. These data will then be converted into GIS format before being stored in geodatabase and used in the developed facility management GIS application.

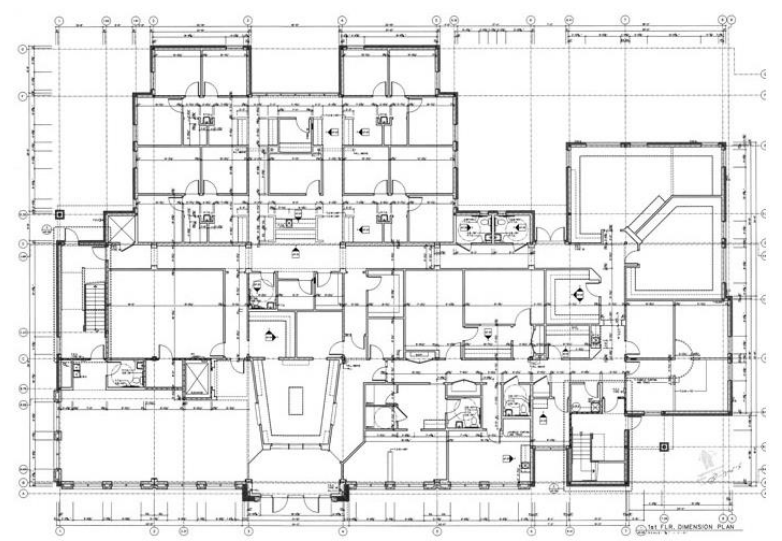

Figure 6. Example of existing as built drawing that need to transform into digital GIS format with attribute insertion.

\subsection{GIS Web Based Application}

GIS web application is an online mapping application that enables authorized user or public to get information on the spatial information such as in our case space and asset management at UKM. Nowadays web GIS comes in many forms and providers from consumer navigational maps to versatile, location analytic tools that allow for user-directed analysis and content discovery (T. R. Baker, 2015). Web GIS is slightly different from GIS software in desktop form.

GIS software usually harder to use and not friendly to layman users. Users who are not with GIS background or nonexperience always find themselves harder to use GIS software as compare to GIS web application. The Web GIS application usually designs to be friendly with the user with fast information retrieval. The capability to present visual in useful manner and can be access from anywhere help to speed the evaluation process. This combination of function addresses the primary difficulties in performing geoscience evaluation (AA. Alesheikh, et al., 2002).

Development of GIS and the evolution of internet have been a catalyst to the improvement of Web GIS. Web GIS have become more useful to the user in term of not only in methods of data acquisition, but also the geoprocessing. The recent technology in Web GIS is cloud based computing platform. This platform provide geoprocessing functions that can bring scalable, on-demand, and cost-effective geoprocessing services to geospatial users (Hao Gong, et al., 2017).

Cloud platform allow data to be store in cloud and share to many user at the same time compare to traditional desktop based where only single user can access the data. This allows the data to be utilized to its full potential. Example of Web GIS providers which provide geoprocessing and cloud storage are ArcGIS Online and Geomap Publisher. This service are the available and top in Malaysia GIS market apart from open source solution which less user friendly.

\subsubsection{Platform}

We utilized the ESRI product ArcGIS Online platform to design and develop the UKM facility management system since it is an affordable solution as for Educational Licenses. ArcGIS Online is a cloud-based mapping and analysis solution. Use it to make maps, analyze data, and to share and collaborate within organization members (ArcGIS Online, 2019). This platform offers a package solution where we also can use their mobile apps linked with the database for site data collection, inspection and updating any facility/assets condition.

\section{UKM ONLINE MAPPING SYSTEM (GIS)}

\subsection{UKM GIS Online System}

UKM has start a rapid GIS-based project/grant since two years ago in order acquire all spatial data, information, basemap, underground utility, asset, space, landscape and other related dataset. All these datasets are then organized in different databases accordingly to their application modules. This modules/sub-systems are developed using ArcGIS Online and ArcGIS Server platforms, only for internal use (assigned staff members for each modules) for better management and operation with cost-efficiency target near the future.

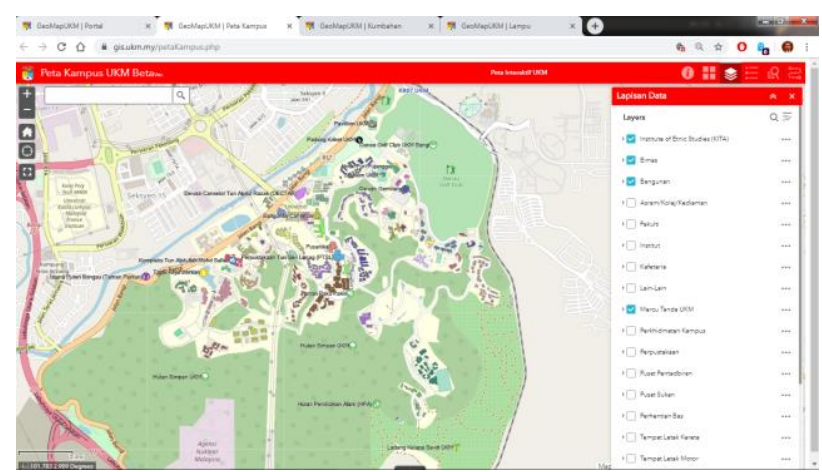

Figure 7. An example of an online UKM campus map.

Currently, we have nine modules in GIS online system where each module have respective (different) database, Graphic User Interface (GUI), analysis and group of users for maintaining the operation/system. 
The International Archives of the Photogrammetry, Remote Sensing and Spatial Information Sciences, Volume XLII-4/W16, 2019 6th International Conference on Geomatics and Geospatial Technology (GGT 2019), 1-3 October 2019, Kuala Lumpur, Malaysia

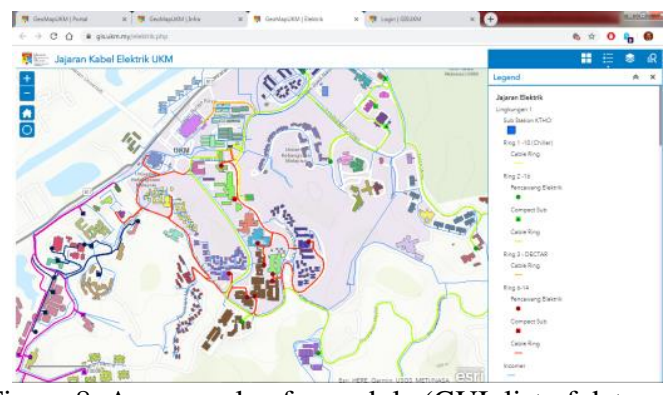

Figure 8. An example of a module (GUI, list of data and analysis) for Electric Cable module (on surface/underground).

\subsection{Developed Module}

The nine developed module in the online mapping system (gis.ukm.my) are illustrate in Figure 9 below.

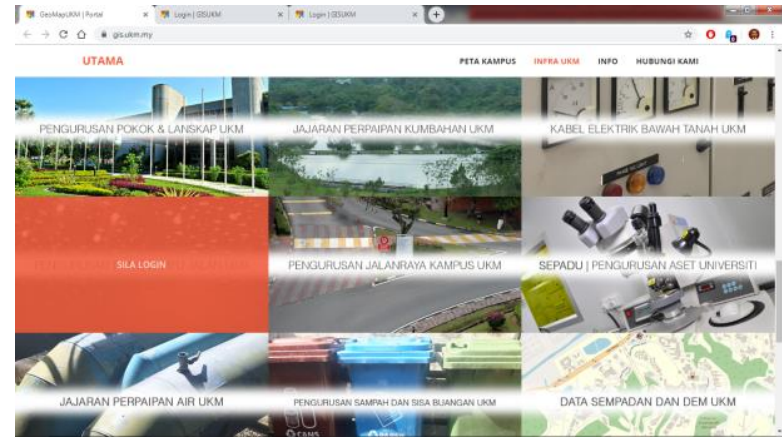

Figure 9 . Current available modules on UKM GIS online portal.

\subsubsection{UKM Landscape and Tree Management}

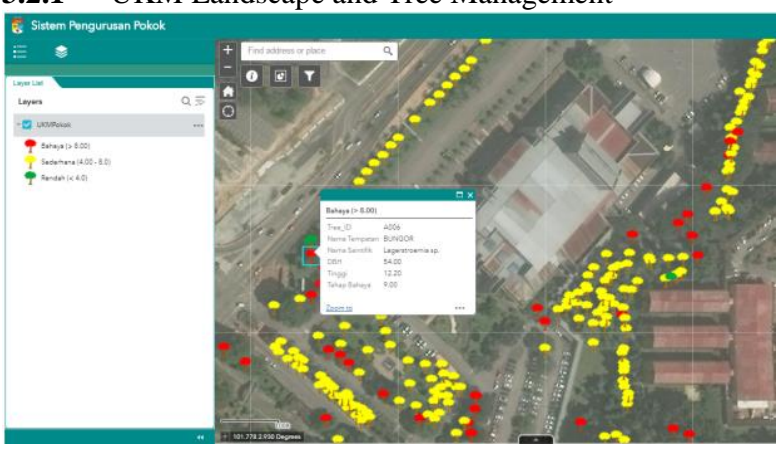

Figure 10. Landscape/tree Management System

\subsubsection{UKM Sepadu/University Assets Management}

This module was developed to establish a spatial database informative management system of buildings, assets and maintenance/services toward them for the internal staff members.

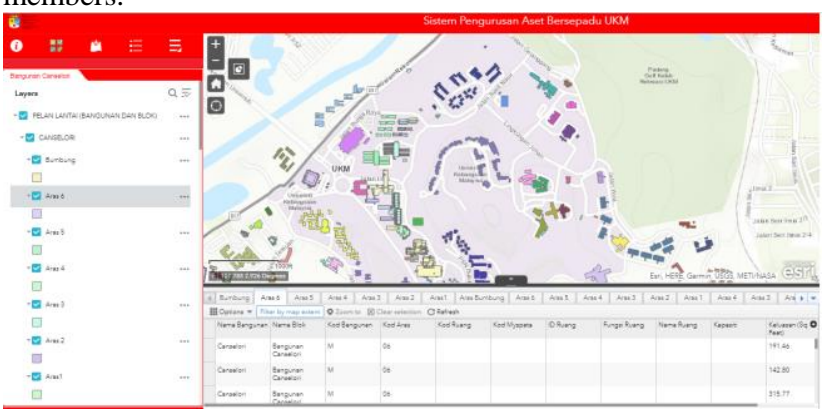

Figure 11. GIS online system for assets management.

\subsubsection{UKM Water Pipe Management}

This module was developed to establish a spatial database and GIS-pipe management information system for maintenance and use to minimize the risk of any construction or maintenance works involving underground utilities (reduce the risk, disturbance and cost for any incident related to water suply in the university).

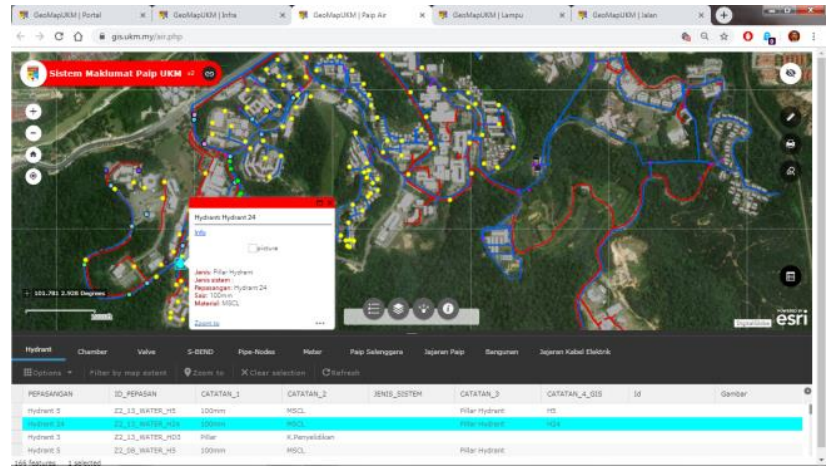

Figure 12. Fresh water pipe information system.

\subsubsection{UKM Waste Management}

The purpose of this module was to establish a spatial database and information management system to acquire locations and information (type of dustbin, capacity, problem/condition and others) for waste daily operation route planning and for the maintenance of assets (bin).

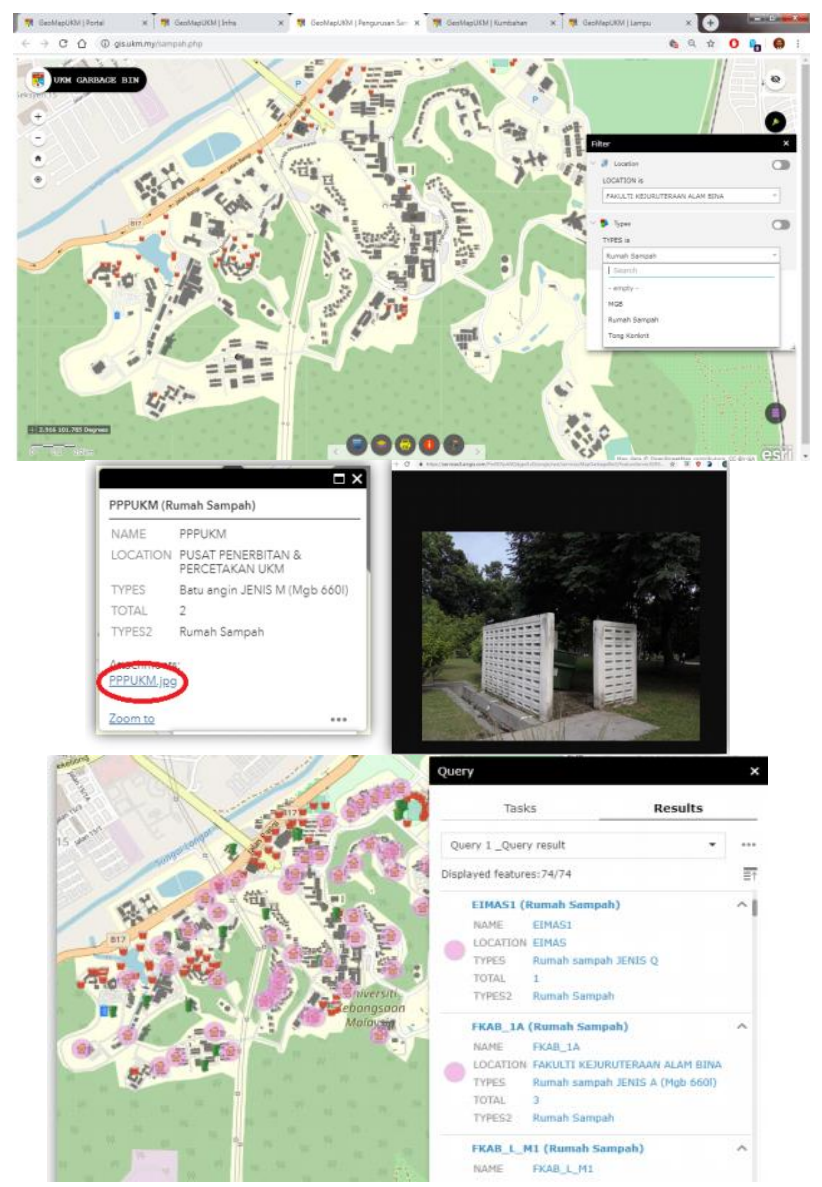

Figure 13. Waste and garbage bin module 
The other five modules are listed below which have different database, GUI, query, reporting, users and person in charge (PIC).

- UKM Oxidation Pipe Management

- UKM Underground Electric Cable

- UKM Street Lamps Management

- UKM Campus Road Management

- UKM Boundary data and DEM (under construction and will be completed soon).

\section{FACILITY MANAGEMENT DATABASE / MODULE - ASSETS AND SPACE}

This section presents the core element of this paper including database and module system on Facility Management (FM) especially on assets and space. The section will be divided into three sub-sections; UKM FM database, system module, and current available analysis.

\subsection{Database}

ArcGIS software (desktop) provide two type of build-in database; personal and file based. A personal geodatabase is a Microsoft Access database that can store, query, and manage both spatial and non-spatial data. While, a file geodatabase is a collection of files in a folder on disk that can store, query, and manage both spatial and non-spatial data (e.g. tabular) (ESRI, 2016).

Both type of available databases capable in supporting attachments, feature-linked annotation, geometric networks, network datasets, parcel fabrics, relationship classes, terrains and topologies. They also able to store the following types of datasets:

- Feature class

- Feature dataset

- Mosaic dataset

- Raster catalog

- Raster dataset

- Schematic dataset

- Table (nonspatial)

- Toolboxes

However, there are some different in the capability of these two databases architecture as in Table 1:

\begin{tabular}{|l|c|c|}
\hline & Personal Geodatabase & File Geodatabase \\
\hline Storage & Max 2 Gb & $\begin{array}{c}\text { Default } 1 \mathrm{~Tb}(1000 \mathrm{~Gb}) 1 \\
\text { Max. 256 Tb }\end{array}$ \\
\hline $\begin{array}{l}\text { Concurrent } \\
\text { users (editing) }\end{array}$ & 1 & $\begin{array}{c}\text { Multi-user with } \\
\text { different editing layer }\end{array}$ \\
\hline
\end{tabular}

Table 1. Comparison of personal and file geodatabase
Thus, for this project, we are working with File Geodatabase ArcGIS desktop architecture with a vast storage capacity and supporting multiple users for simultaneous editing process.

\begin{tabular}{|c|c|c|}
\hline BuildingInformationUKM.gdb & \begin{tabular}{|l|l|l|} 
Contents & Preview & Description \\
\end{tabular} & \\
\hline (由) 它 ATMA & Name & Type \\
\hline 丹它 DECTAR & DJatMa & File Geodatabase Feature Dataset \\
\hline (4) DewanAnuwarMahmud & GDEECTAR & File Geodatabase Feature Dataset \\
\hline (4) DewanGemilang & 马ewanAnuwarMahmud & File Geodatabase Feature Dataset \\
\hline (t) S DTAMS_Dewan & DewanGemilang & File Geodatabase feature Dataset \\
\hline (t) FEP FEP & çDTAMS_Dewan & File Geodatabase Feature Dataset \\
\hline (t) 它 FKAB_BangunanBaru & 㝍FEP & File Geodatabase Feature Dataset \\
\hline (1) FKAB_BangunanLama & FFAB_BangunanBaru & File Geodatabase Feature Dataset \\
\hline 田它 FPI & DFFAB_BangunanLama & File Geodatabase Feature Dataset \\
\hline FSSK & 号FPI & File Geodatabase Feature Dataset \\
\hline 田它FST_BIO & DFFsSK & File Geodatabase Feature Dataset \\
\hline ๑官 FTSM & DFFST_BIO & File Geodatabase Feature Dataset \\
\hline 田号FUU & GFTSM & File Geodatabase Feature Dataset \\
\hline (t) GSB & 马Ffu & File Geodatabase Feature Dataset \\
\hline 田 㽞 IPI & 它GSB & File Geodatabase Feature Dataset \\
\hline 田号 JPp & 号IPI & File Geodatabase Feature Dataset \\
\hline (7) KAB & 官.jpp & File Geodatabase Feature Dataset \\
\hline (1) $\mathrm{KBH}$ & WKaB & File Geodatabase Feature Dataset \\
\hline 田官 KDO & फु $\mathrm{KBH}$ & File Geodatabase Feature Dataset \\
\hline 由号 KIV & 它 KDO & $\begin{array}{l}\text { File Geodatabase Feature Dataset } \\
\text { File Geodatabase Feature Dataset }\end{array}$ \\
\hline 田宫 KKM & Б大KM & File Geodatabase Feature Dataset. \\
\hline (t) Kompleks_Akademik & Gompleks_Akademik & File Geodatabase Feature Dataset \\
\hline $\begin{array}{l}\text { (1) Kompleks_Bestan } \\
\text { Konyelidikan }\end{array}$ & $\begin{array}{l}\text { S5ompleks_Bestari } \\
\text { S5Kompleks_Penyelidikan }\end{array}$ & $\begin{array}{l}\text { File Geodatabase Feature Dataset } \\
\text { File Geodatabase Feature Dataset }\end{array}$ \\
\hline 田占 KPZ & 它 KPZ & File Geodatabase Feature Dataset \\
\hline KTHO & ФБКкто & File Geodatabase feature Dataset \\
\hline (†) KUO & 邞kuo & File Geodatabase Feature Dataset \\
\hline 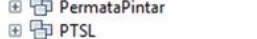 & 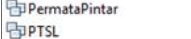 & $\begin{array}{l}\text { File Geodatabase Feature Dataset } \\
\text { File Geodatabase Feature Dataset }\end{array}$ \\
\hline
\end{tabular}

Figure 14. UKM FM building geodatabase (file geodatabase)

For a faster query (quick access) on building information (attribute) or geometry (as-built floor level), the arrangement of the file in this database are placed base on building name. Within the building, the next level of arrangement is as-built by floor, rooms and lastly the assets in each room as related (relationship).

$$
\begin{aligned}
& \boxminus \square \text { BANGUÑNAN.gdb } \\
& \boxplus \text { 它 BALAI_RAYA_PERUMAHAN_BUKT } \\
& \boxplus \text { B BANGUNAN_WAWASAN } \\
& \boxplus \text { BIOSERASI_MAKMAL } \\
& \boxminus \text { 吕 CANSELORI } \\
& \text { 圖 Paras_1 } \\
& \text { 望 Paras_1_Aset_Baru } \\
& \text { 圖 Paras_2 } \\
& \text { 品 Paras_2_Aset_Baru } \\
& \text { 圖 Paras_3 } \\
& \text { 聶Paras_3_Aset_Baru } \\
& \text { 圆 Paras_4 } \\
& \text { 品 Paras_4_Aset_Baru } \\
& \text { 國 Paras_5 } \\
& \text { 國 Paras_5 } \\
& \text { 圖 Paras_6 } \\
& \text { 望 Paras_6_Aset_Baru }
\end{aligned}
$$

Figure 15. UKM FM building geodatabase, level floor/room and asset relationship. 
The International Archives of the Photogrammetry, Remote Sensing and Spatial Information Sciences, Volume XLII-4/W16, 2019 6th International Conference on Geomatics and Geospatial Technology (GGT 2019), 1-3 October 2019, Kuala Lumpur, Malaysia

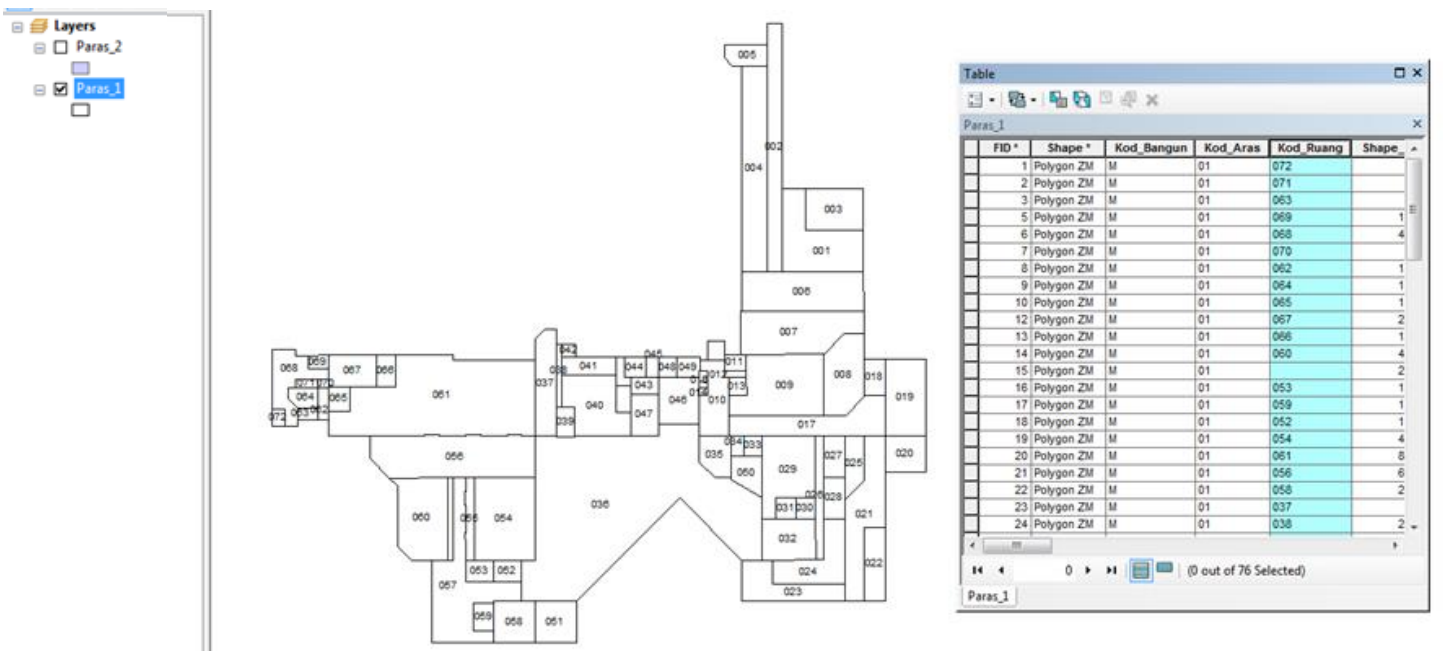

Figure 16. An example of UKM FM Chancellor building, 1st floor, as-built geometry and attribute/information in a GIS viewer.

4.2 The FM System Module (Sistem Pengurusan Aset Bersepadu UKM)
This system module has two different GUI; operational level (Figure 17) and new dashboard view for the decision makers (top management) as illustrate in Figure 18.

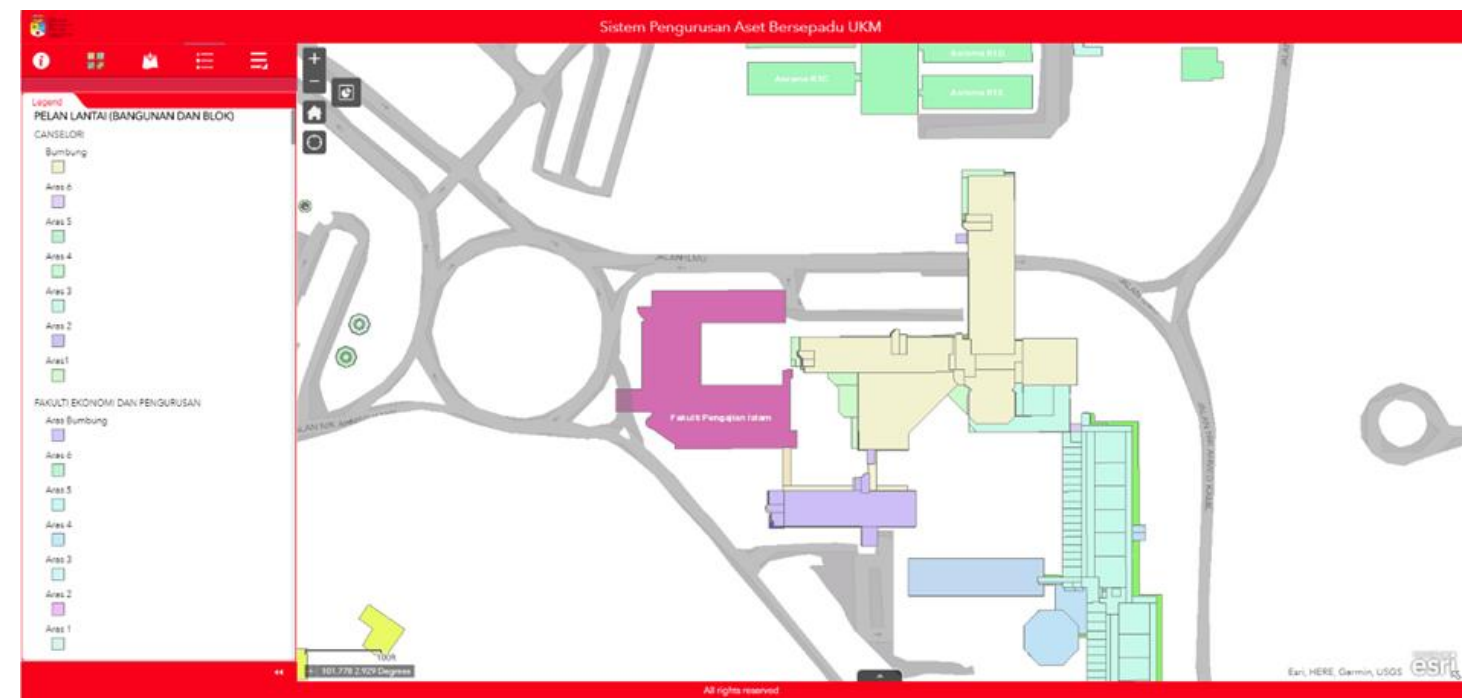

Figure 17. FM Module GUI for operational

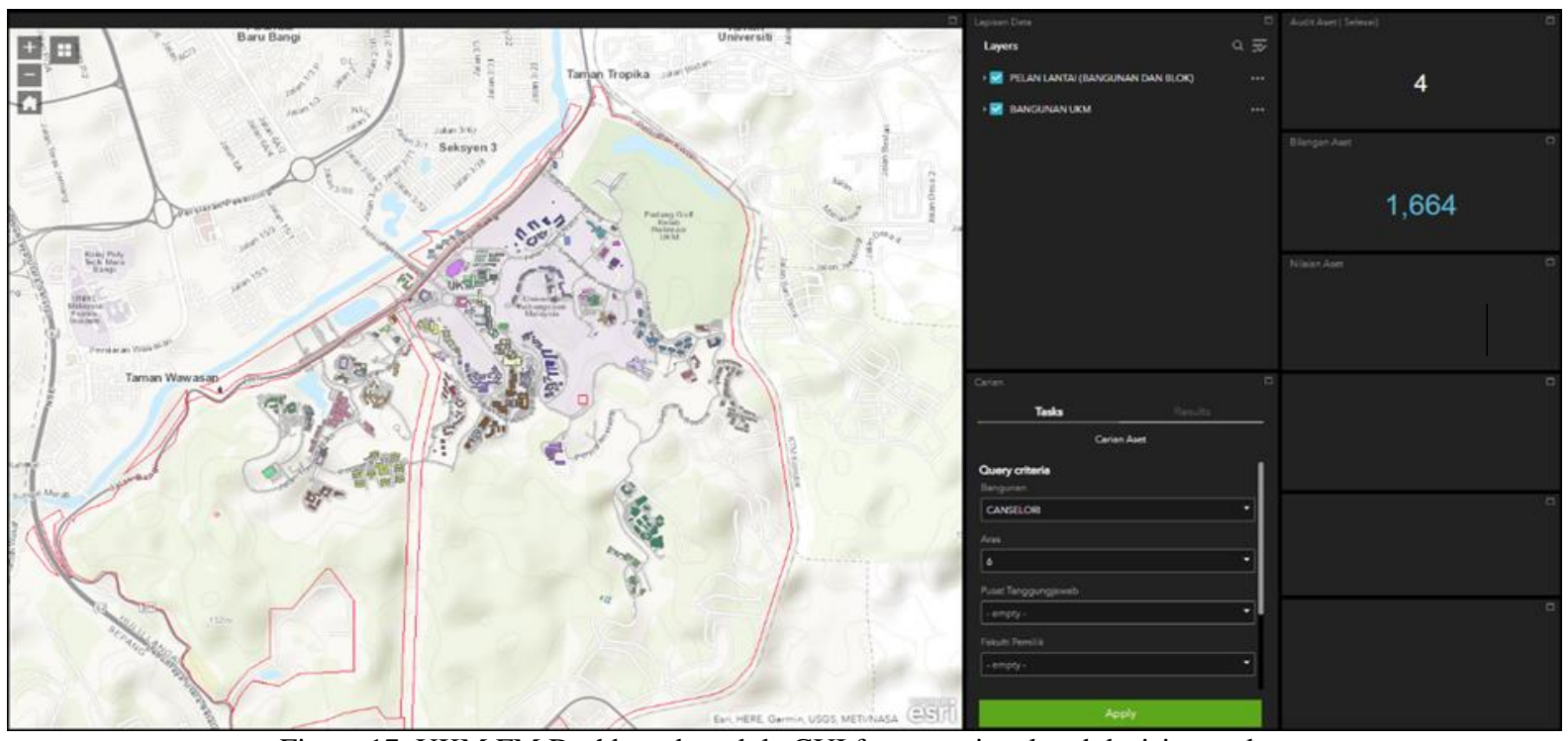

Figure 17. UKM FM Dashboard module GUI for operational and decision maker. 
The International Archives of the Photogrammetry, Remote Sensing and Spatial Information Sciences, Volume XLII-4/W16, 2019 6th International Conference on Geomatics and Geospatial Technology (GGT 2019), 1-3 October 2019, Kuala Lumpur, Malaysia

\subsection{FM Analysis}

For the analysis part, retrieval from the database is our main concerned. All attribute information as well as the assets, image and space related data shall be drawn and showed in this dashboard such as query on a building floor (Figure 18). Statistics figures such as total number of assets and value of assets (RM) per screen view/total will be shown.
Near the future, if possible, we plan to upload the risk assessment analysis result (from desktop analysis) on asset and space (such as damage of a building caused by fire or etc) as for more informative system.

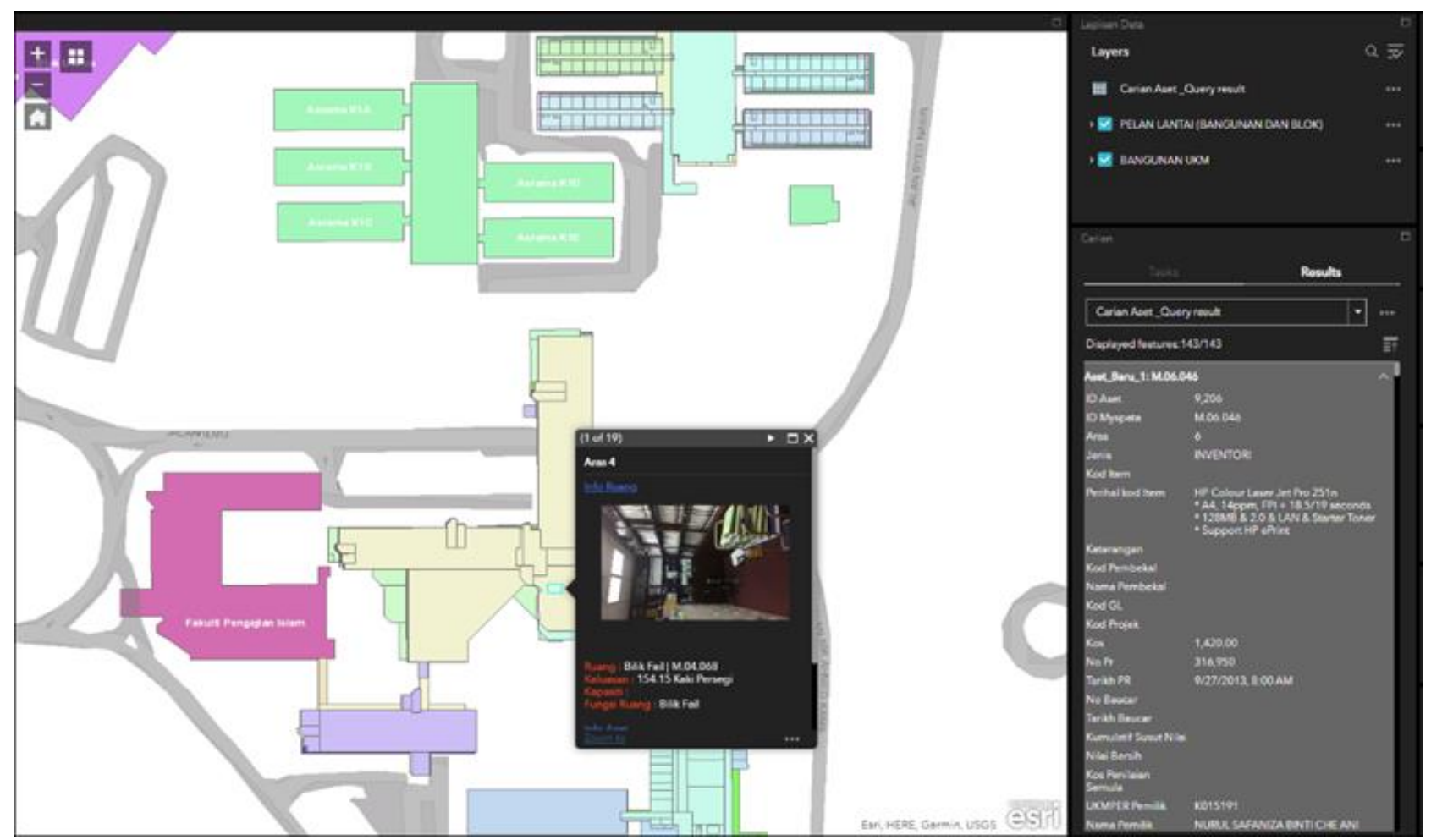

Figure 18. Example of query/searching in UKM FM Module

\section{CONCLUSION}

As for the conclusion, this paper describes the current implementation of GIS system in UKM Bangi, especially for spatial data collation, spatial database creation, development on so called one-stop-GIS-portal that hosted the targeted modules. The development of this system from data gathering took almost three years and at the moment, these system/module are very useful for UKM operation.

The aim and objectives of this working grants has been accomplished and this paper basically as a sharing medium/references to other organizations/universities or researchers for their implementation as for the discussed modules.

UKM facility management system (SEPADU) is an internal system (cannot be accessed by public) and only for the selected personnel who dealing with space and assets management. Our return of investment (ROI) for this implementation will be sooner than expected and they are indeed will be time-cost efficient solution for long run on FM maintenance at UKM.

For the future work, we would integrate this system with existing system (Ufast - a treasury system) for better spatial visualization and information retrieval.

\section{ACKNOWLEDGEMENT}

This research and development of the system is funded by Strategic Research Grant (category optimum and strategic wealth) of Universiti Kebangsaan Malaysia (UKM), Selangor, Malaysia. Grant Number KRA-2018-020, KRA-2018-019 and KRA-2018-048

\section{REFERENCES}

AA. Alesheikh, H. Helali, HA. Behroz. (2002). Web GIS: Technologies and Its Applications. Symposium on Geospatial Theory, Processinh and Applications, 1.

Abdul Hakim bin Mohammed. (2006). The Implementation of Asset and Facilities Management System in the Malaysian Government Agencies. Professorial Inaugural Talk, 3.

ArcGIS Online, 2019. https://doc.arcgis.com/en/arcgisonline/get-started/what-is-agol.htm [Access date Sept 2019].

Balasubramanian, P. A. (2017). Four Data Models in GIS. In P. A. Balasubramanian, Four Data Models in GIS (p. 20). Mysore: DOS in Earth Science-MYSORE, University of MYSORE. 
The International Archives of the Photogrammetry, Remote Sensing and Spatial Information Sciences, Volume XLII-4/W16, 2019 6th International Conference on Geomatics and Geospatial Technology (GGT 2019), 1-3 October 2019, Kuala Lumpur, Malaysia

Cantwell, B. and Milem, J.F., 2010. Locating Space and Place in the College Access Debate: New Tools for Mapping and Understanding Educational Inequity and Stratification. International Encyclopedia of Education (Third Edition), Pages 636-648. https://doi.org/10.1016/B978-0-08-044894-7.00120-2

Che Mohd Nasir, Siti Nuratirah. (2018). Rules of Facilities Manager in Producing and Outstanding Interior Design. APGC $\mathrm{UM}, 2$.

ESRI, 2016. ArcMap Geodata. Online article http://desktop.arcgis.com/en/arcmap/10.3/main/manage-data/ [Access date Sept 2019].

ESRI, 2007. A Framework for Understanding, Managing, and Improving Our World. In ArcNews Online 2007. https://www.esri.com/news/arcnews/fall07articles/gis-thegeographic-approach.html

ESRI. (2010). GIS Best Practices: Facilities Management. In K. Ricahardson, GIS Gives Port a Common Operating Picture (p. 13). United States: ESRI.

Ewan Masters, Bemd Hitsh and Ken Wong. (1994). GPS/GIS and Space Time Data. 1.

FMA (2012). Facilities Management Good Practice Guide. Melbourne: Facility Management Association of Australia Ltd (FMA Australia).

Grace L. Samson, Joan Lu, Mistura M. Usman, Qiang Xu. (2017). Spatial Databases: An Overview. In J. L. Grace L. Samson, Spatial Databases: An Overview (p. 111). United States of America: IGI Global.

Grimshaw, D. (1994). Geographical information systems: A Tool for Business dan Industry? Journal of Information Management, 9(2), 119-129.

Hairi Karim, Dato Abdul Latif Abu Seman, Mohamad Azrol Mohamad Dali, Siti Zurianah Othman, and Siew Chengxi Bernad, 2019. A Proposal to Implement Integrated GIS System in Disseminating Spatial Information for Malaysia Development Approval (Stakeholders and Applicants) - A Concept Paper. GGT 2019 [In progress].

Hao Gong, Matamyo Simwanda, Yuji Murayama. (2017). An Internet-Based GIS Platform Providing Data for Visualization and Spatial Analysis of Urbanization in Major Asian and African Cities. ISPRS International Journal of Geo-Information, 2.

Longley, P.A Goodchild, M.F., Maguire, D.J. and Rhind, D.W. (2001). Geographic Information Systems and Science. Wiley, West Sussex, 454.

Marion W. Mwaniki, Patroba A. Odera. (2012). Application of GIS in Faciliy Space Management: A Case Study of ILRI. International Journal of Science and Research (IJSR), 1.

Manson. M. Steven, Dudley B.Bonsal, Melinda Kernik, Eric F.Lambin, 2015. Geographic Information Systems and Remote Sensing. International Encyclopedia of the Social \& Behavioral Sciences (Second Edition), 2015 Pages 64-68. https://doi.org/10.1016/B978-0-08-097086-8.91027-4
Mahmoud M.R Halfawy, Linda A. Newton, Dana J. Vanier. (2006). Review of Commercila Municipal Infrastructure Asset Management Systems. ITcon Vol. 11, 211.

Mohd Nazali Mohd and Micheal Pitt. (2008). Defining Facilities Management (FM) in the Malaysian Perspective. IJMU.ac.uk, 9.

M. Aizat Saiful Bahri, Soheil Sabri, Fozial Johar, Zohreh Karbassi, M. Rafee Majid, Ahmad Nazri Muhamad Lidin., 2014. Comparison of Spatial Autocorrelation Analysis Methods for Distribution Pattern of Diabetes Type II Patients in Iskandar Malaysia Neighbourhoods. International Conference on Urban and Regional Planning 2014.

Pingel, T. J. (2018). The Raster Data Model. In T. J. Pingel, The Raster Data Model (p. 1). Washington, DC: Association of American Geographers.

Ross S. Lunetta, Russell G. Congalton, Lynn K. Fenstermaker, John R. Jensen, Kenneth C. McGwire, Larry R. Tinney. (1991). Remote Sensing and Geographic Information System Data Integration: Error Sources and Research Issues.

Photogrammetruc Engineering \& Remote Sensing, 677-687.

Sabi'u, N., Muhammed, S.N., Zakari, N. And Khalil, M.S. (June 2015). Vector Data Model in GIS and How it Underpins a Range of Widely Used Spatial Analysis Techniques. Dutse Journal of Pure and Pplied Sciences 1(1), 122.

T. R. Baker. (2015). Chapter 9: WebGIS in Education. In A. D. Osvaldo Muniz Solari, Geospatial Technologies and Geography Education in Changing World (p. 105). Japan: Springer Japan KK.

Revised September 2019 